\title{
Analysis of The Effect of Employee Age, Human Resource Management Practices and Employee Competence on Employee Performance in Kenyan State Corporations
}

\author{
Christopher Masinde Indiatsy ${ }^{1}$ Prof. Peter K'Obonyo ${ }^{2}$ Dr. Florence Muindi ${ }^{3}$ Dr. Mercy Munjuri ${ }^{4}$ Dr. Iraya \\ Cyrus Mwangi ${ }^{5}$ \\ 1. School of Business. University of Nairobi. P. o Box 30197, Nairobi Kenya. \\ 2. School of Business. University of Nairobi. P. o Box 30197, Nairobi Kenya. \\ 3. School of Business. University of Nairobi P. o Box 30197, Nairobi Kenya. \\ 4. School of Business. University of Nairobi P. o Box 30197, Nairobi Kenya. \\ 5. School of Business. University of Nairobi. P. o Box 30197, Nairobi Kenya.
}

\begin{abstract}
Age plays an important role in a wide range of employee behaviors that determine their performance. Measurement of employee performance indicates organization performance. This study was anchored on the premise that, age alone is not sufficient to determine employee performance, other factors come in as moderators. The study objective was to investigate the joint effect of employee age, human resource management practices and employee competence on employee performance as compared to the effect of the individual predictor variables on employee performance in Kenyan state corporations. A descriptive cross sectional survey research design was used to find out the relationship between the study variables. A population sample of 384 employees was drawn using Webster (1995) formula. A stratified and simple random sampling technique was used to pick the number and type of respondents. The study relied on primary data collected on employee age, HRM practices, employee competence and employee performance using a structured questionnaire. Descriptive and inferential statistics were used to analyze the data. Pearson product moment correlation (r) assessed the relationship between the study variables and stepwise regression analysis technique was used to test the study hypotheses. Results indicated a statistically non significant relationship between employee age and employee performance. The study confirmed that HRM practices and employee competence significantly influenced the relationship between employee age and employee performance. It was also confirmed that the joint effect of the study variables was greater than the effect of the average individual predictor variables on employee performance. The study concludes that age alone is not enough to make decisions on issues pertaining human resource management such as recruitment, placement and retirement. It is recommended that State Corporations should formulate human resource policies and practices that will help reap maximum benefits from their employees. The study extends the body of knowledge in age management practices. Policy makers in state corporations should consider applying these study variables jointly rather than individually to effectively improve employee performance.
\end{abstract}

Key words: State corporations, employee age, employee performance, moderators, competence, HRM practices, variables, correlation, regression, significance, theory, effect, analysis and measurement.

DOI: $10.7176 / \mathrm{EJBM} / 11-30-14$

Publication date:October $31^{\text {st }} 2019$

\subsection{Background of the Study}

Considerable academic and practitioner interest has existed in the relationship between age of employees and employee performance due to extension of individual lifespan and the fall in birth rate in developed countries leading to increased proportion of older people outside the workforce to be supported by a smaller base of working adults (Karpinen, 2011). Developing countries, unlike developed countries, have high birth rates with majority of the population consisting of young people, a situation leading to high rate of unemployment and high dependency 
ratio (Eiker, 2009). Age plays a vital role in varied employee behaviors which determine their performance (Boulander, 2007). Measurement of employee performance gives an indication of the effectiveness of an organization to achieve its overall strategic goals and objectives. Age alone is not sufficient to determine employee performance (Armstrong, 2006). Other factors such as competence, determined by education/skills level, experience and human resource management practices have been found to affect this relationship. Booz et al. (2009) examined the employee's age, powers of an employee and his work experience in an occupation. Results of previous studies indicate that age and experience exhibit a core linear relationship with performance. Human resource management (HRM) practices influence employee behaviors which in turn enhance performance by improving their competency in the international labor market (US Department of Labor, 2007).

The current study is based on Expectancy Theory, Human Capital Theory and Continuity Theory. Expectancy theories of Vroom (1964) and Porter (1968), posit that performance does not depend only on the magnitude of exerted efforts but also on other factors such as individual abilities, traits and role perceptions which can be influenced by age, skills level and education. In this study, the implication is that age which determines the magnitude of efforts, is not on its own, an effective determinant of employee performance unless other factors such as educational level, skills level and training come in as its moderators. Human capital theory explains that widespread investment in human capital in terms of education and training creates a skill-base in the labor force indispensable for economic growth (Borman et al.,1991). Continuity theory posits that successfully ageing individuals maintain positive habits, lifestyles, preferences, and relations in the middle age and later which maintains or improves their performance (James et al., 2011). It can therefore be deduced that large amounts of energy exerted by an individual may still result in low performance if they are not supported by competence and motivational factors. In this study, employee age, HRM practices and employee competence are believed to influence the performance of employees more than the individual role of employee age.

Age as an independent variable was selected because many studies such as Lewin (2006) have demonstrated that age influences a number employee behaviors that determine his/her performance. HRM practices were selected for this study because they are performance enhancing activities that influence a wide range of employee behavior at work (Omari, 2012). The behaviors include, commitment, trust, job satisfaction and organization citizenship behaviors. Employee competencies were selected because they are general ability descriptions an employee needs in performing a task or a role in the organization. They are a signal from the organization to individual employees of the expected areas and levels of performance (Carstenson, 2005). Employee competencies can be manifested through their education levels, skill levels, levels of training and experience (Armstrong, 2008). The existing literature, such as Graham (2007) has established that a relationship exists between employee age and employee performance. On the other hand a number of studies (such as Omari, 2012) have established a non significant relationship between employee age and employee performance, implying that age alone is not sufficient to determine employee performance. The current study investigated this relationship in Kenyan State Corporations.

Studies have shown that, on the average, age alone accounts for little variance in work performance, suggesting that other factors come into play to moderate the relationship (Davel, 2000). This relationship is weak in the absence of variables such as HRM Practices and employee competence. The effect of the link moderating between employee age and employee performance has not been adequately addressed in the existing literature. Expectancy theorists like Porter, Vroom and Lawler posit that other than magnitude of efforts, performance also depends on other factors such as individual abilities, traits and role perceptions which can be influenced by factors such as age, education and skills level. Employee age and performance are moderated by characteristics and abilities of individuals (including competence). Many studies use certain employee factors such as age and competence to explain employee performance. The simultaneous role played by HRM Practices and employee competence in stepping up employee performance needs to be investigated. The current study contributed by adding this input to the body of literature. The main objective of the current study was to establish whether the joint effect of employee age, human resource management practices and employee competence on employee performance is greater than the effect of individual predictor variables on employee performance in Kenyan state corporations.

\subsubsection{Employee Age}

Swarthert (2015) defines employee age as the minimum age of admitting an individual into employment up to retirement time. The minimum legal working age in a given country or jurisdiction varies with the type and nature of work (Menounis, 2015). International Labor Organization (ILO) put the minimum age for admission into employment or work for young persons, as eighteen years. The contradictory theoretical evidence regarding age in relation to ability and motivation coincides with mixed results reported by previous researches. Boulander (2007) asserts that as employees advance in age, they gain a wealth of experience and expertise and can be used to train new and young employees. In acknowledging the wealth of experience and expertise of older workers, Maitland (2013) notes the absence of experienced older engineers with discomfort. On the other hand, Graham 
(2007) asserts that younger workers are preferred as they are more up to date than their older counterparts as they can be trained faster and easily adapt to changes.

For developing countries where population is ageing, governments spend heavily on retired employees in terms of social welfare and pensions paid to the retirees who do not contribute to the national income of their countries (Delsen, 2009). Transfer payments in form of pensions and grants paid for social welfare and to retired workers are equally a big problem to developing countries (Borman, 1991). This situation is forcing many world economies to reconsider and start restructuring their policies such that very soon it is certain that many people over the present retiring age will have to work (Cole, 2008). This is believed to be the idea behind extending retirement age. The extension of retirement age in the Kenyan public service from fifty five to sixty years has aroused interest in studying the linkage between employee's age and employee's performance and the rationale of this structural state decision. Organizations need to put in place, age management practices to maximize the performance of their existing employees

\subsubsection{Human Resource Management Practices}

Human resource management practices are performance-enhancing activities that improve employee competitiveness and hence performance (Ochoti, 2011). Organizations put in place varied adopt performanceenhancing human resources management (HRM) practices to enhance their competitiveness globally (U.S Department of Labor, 2012). HRM practices, motivate, attract and retain employees to improve their performance and hence organization productivity (Schuler and Jackson, 1987). Human resource management practices are meant to enhance human capital which is key in achieving organization objectives and goals (Delery and Doty, 2010). The efficient application of HRM practices enhances employer and employee contribution and commitment to the organization (Purcell, 2003).

HRM practices were chosen for this study because they influence a wide range of employee behavior which enhances their performance at work (Omari, 2012). The behaviors include, commitment, trust, job satisfaction and organization citizenship behaviors. A study conducted in the textile sector of Japan by Hassan (2016) analyzed the linkage between human resource management practices and employee performance. The findings indicate a positive relationship between the two.

\subsubsection{Employee Competence}

Competence is defined as the ability to do a particular activity to a prescribed standard (Lidden, 2007). It is an outcome which describes what someone can do and does not describe the learning process which the individual has undergone (Hollyford, 2007). Employee competencies refer to descriptions of the abilities of an employee to perform a role in the organization. They are a signal from the organization to individual employees of the expected areas and levels of performance (Carstenson, 2005). Employee competencies can be manifested through their education levels, skill levels, levels of training and experience (Armstrong, 2008).

Competence is linked to individuals, institutions or groups as they acquire or posses abilities in achieving specific goals or objectives. According to Eicker (2009) competencies have provided organizations a way to determine what employees need, to produce results the organization desires. Competencies, enables organizations to evaluate the ability to perform various tasks (Cascio,2009). According to Carstenson (2005), employee competencies can be integrated into performance in various ways such as hiring practices, succession planning, performance appraisals, as well as orientations and employee communication. Knowledge and skills are required in a competent work force. In the current study it is one of the moderating variables.

\subsubsection{Employee Performance}

Employee performance is the ability of an employee to carry out a piece of work, duty or expected tasks according to an established standard (David, 2010). Campbell (2013) defines employee performance as an individual level based variable or tasks, a worker performs in an organization. This distinguishes it from extreme constructs like organization productivity, considered to be high level variables (Collins, 2005). Employee performance is an essential concept in management research. Measurement of performance gives an indicator to the organization's productivity.

A corporation should be related to its performance, manifested in its overall effectiveness (Musyoka, 2010). Performance management of employees is a strategy that establishes a shared work force to understand what is to be achieved by an organization. To achieve this business strategy there is need to create a high performance workforce (Mowday, 2009). Measuring performance of employees has been a major challenge for a number of 
practitioners and scholars. Staw (2006) proposes that performance be staged at the level of individual, group or organization. It can be evaluated on the basis of task performance (Muindi, 2014) and contextual performance (Casey,2007).

\subsubsection{State Corporations}

State Corporations are organizations formed through an Act Parliament (GOK, 2015). They are key players in the economic growth and development of Kenya. Kenya has187 State Corporations based in different sectors of the economy including transport, communications, agriculture, manufacturing and trade (TPPR, 2013). The corporations are under the State Corporations Act (CAP 446) of the Laws of Kenya (GOK, 2015). Their establishment was aimed at accelerating economic and social development including increased participation of Kenyan citizens in the economy.

The focus on employees of state corporations in this study was driven by the fact that this sector plays a critical role in Kenya's economic growth and development by providing essential goods and services at low cost, hence the need to improve the human resources for better performance in the sector (Omari,2012). The study was carried out in the background of change in the public sector in Kenya and shifts in management systems affecting employee performance in the said corporations. The systems are performance contracts, performance appraisal and performance ranking making the sector competitive (GOK, 2015).

The introduction of performance contracts in state corporations implies that performance is key and human resources management practices are the basis of improving productivity in this sector. State Corporations in Kenya are managed by management boards led by a chairman who is a presidential appointee, a chief executive officer and the permanent secretary of the parent ministry, treasury permanent secretary and seven other members appointed by the minister.

\subsection{Research Problem}

The influence of employee age on employee performance is becoming an issue of concern in many organizations. Age determines varied employee behaviors such as performance, commitment, intentions to quit, job satisfaction, and organization citizenship behavior (Boulander, 2007). Scholars such as Liden (2007) have argued that employee age alone is not sufficient to fully determine his/her performance in the absence of other factors. Human resource management practices influence employee performance. This implies that expended efforts without these abilities and traits results in low levels of performance. Many studies such as Omari (2012) have also established a non significant relationship between employee age and employee performance. These researchers did not come across any study done in Kenyan State Corporations to show whether this finding would hold in the presence of other factors or under different conditions.

The focus on these Corporations is driven by the fact that the sector makes an important contribution to Kenya's economy. However, as seen earlier, some of these organizations are economically unviable due to old technologies, financial mismanagement, poor structures and malpractices (Obare, 2006). To make them viable, there is need to come up with strategies on age management practices that will enhance their performance. To achieve the vision 2030, it is important to have efficient and productive state corporations with competent and productive employees. Previous studies have concentrated in developed nations, failing to portray the same results in developing countries due to differences in cultural and economic backgrounds. The present study focused on a developing country, namely Kenya. The study sought to assess the joint effect of Employee Age, Human Resource Management Practices and Employee Competence on Employee Performance as compared to the effect of individual predictor variables on Employee Performance.

\subsection{Objective of the Study}

The objective of the current study was to establish whether the joint effect of employee age, human resource management practices and employee competence on employee performance is greater than the effect of individual predictor variables on employee performance in Kenyan state corporations. 


\subsection{LITERATURE REVIEW.}

\subsection{Theoretical underpinning of the study}

What is the driving force behind employee performance? Campbell et al. (2013) posits that employee performance refers to their work related behaviors or actions representing their contribution to the organization in form of outputs or outcomes. Since employee performance is a behavior, this research's theoretical underpinning was explained using employee behavior, which are organization behavior theories. Theoretical underpinning of the study therefore, was based on various theories of aging, employee performance, motivation and competence. These are theories explaining the relationship between the variables employee age and employee performance and how it is influenced by moderating variables. These are the Expectancy theory, Human capital and continuity theories.

\subsection{Employee Age and Employee Performance}

A growing number of published articles on behavioral science journals, have reported age performance correlations. Monika (2016) investigated the relationship between employee average age, and their performance work ability. Analysis was conducted on data from 90 German companies in Manufacturing industries with 12,000 employees. Results showed that employee average age was negatively related to employee work ability. Meta analysis studies on procedures, found that employee age and work performance were correlated (Wayne, 2009). The measured performance (productivity versus ratings) and job type (professional versus non professional) significantly moderated the relationship between employee age and their performance.

A study conducted by Grand (2005) explored the interaction between corporate age structures and performance of employees. Issues were addressed to find out if firms with more younger employees were more successful than those with more older employees and whether firms with homogenous or heterogeneous work forces are performing well (Stephen, 2015). Danish linked employer - employee data, was used and findings revealed that the mean age and age dispersion in the study firms were inversely U-shaped related to performance (Grand, 2005). Kanagaraj (2017) examined the area of age diversity of the workforce, with particular reference to the relationship with employees' performance. As a result of the research carried out, age diversity appeared to be the main driving force behind employees' performance.

\subsection{Employee Age, HRM Practices and Employee Performance}

Growing changes in retirement ages and an aging workforce is a global predicament that has initiated a growing interest on potential contribution of relevant bundles of HRM practices to enhance performance among ageing workers (Akhter, 2013). Lifespan theories of development and self-regulation highlighted on various bundles and types of HRM practices aim at helping individual workers reach higher levels of performance through various challenges. Currently companies gain strong competitive advantage through effective and efficient HRM practices.

If properly administered HRM practices contribute heavily to organization productivity and success (Dorien et. al., 2013). Efficient and effective management of human resources is achieved through implementing sound HRM practices. HR Managers can make employees happier and more productive by providing positive training and enjoyable work environments that help retain talent (Huselid, 2004 and Nida, 2017). The performance levels in the face of challenges such as performance appraisal practices and ratings are the means by which a business sets out to achieve its desired goals on human capital (porter, 2008).Varied HRM practices will differently influence age cohorts and categories of various employees (porter, 2008 and Kariuki, 2015).

Alum (2013) investigated the effect of HRM practices on worker performance. The study was carried out in a cement industry in Bangladesh. Findings indicated that HRM practices positively influenced employee performance. The current study embraces HRM practices as a moderator in the relationship between employee age and employee performance.

2.4 Employee Age, Employee Competence and Employee Performance Studies like Gregory (2015) have established that employee performance and competence are closely related in terms of individual abilities, experience and motivation. Competencies describe the abilities needed to perform a task or a role in the organization. They are terms that can be measured. They are a signal from the organization to individuals of the 
expected areas and levels of performance (Wooldridge, 2009). Employee competencies can be manifested through their education levels, skill levels, levels of training experience and talents (Wirtz, 2005).

In terms of comparing the competencies between the young and the old, younger people are preferred by employers for a number of reasons. Young workers have completed their education more recently, are more innovative and flexible in their attitudes towards change compared to older workers who prefer maintaining the status quo (Graham, 1998). On the contrary, Boulander (2007) asserts that employees gain a wealth of experience and expertise as they advance in age. Hence their performance is relatively higher than their younger counterparts (Torrington, 2005). Smith (2014), the Vice president of Boarders, a national book seller says, our over 50 employee's turnover is ten times less than the under 30. The inadequacies and limitations of these past studies cannot verify the fact that young workers are better than older workers. This study attempts to contribute to the debate by incorporating moderating variables.

Susanna (2006) examined conceptions of employees on the meaning of experience in job-competence and development in their work environment. The study aimed to bring out a variety related conception to experience, workplace learning and competence. Results indicated that employees view experience and work place learning as most important to improved productivity. They pointed work experience as their main source of competence.

\subsection{Employee Age, HRM Practices, Employee Competence, and Employee Performance}

Adopting a variety of performance enhancing human resource management practices has been the aim of the major US companies to improve their competitiveness in the global market place (US state department of labor, 2012). The management approaches, styles and organization practices, can influence employee performance. HRM practices such as employee participation and empowerment, compensation benefits (pay), employee training and development and employee welfare benefits improve employee performance. A variety of HRM practices enhance employee skills and competence (Ochoti, 2011). Efforts aim at improving the quality of individual skills, abilities and motivation through training and apprenticeship (Altimes, 2005). Performance is always multidimensional. Performance requires more important types of behavior or skill for overall success (Schmdt, 2014).

The effectiveness and productivity of skilled employees will however decline, if they are not well motivated to perform their jobs. Huselid (2004) posits that the form and structure of an organization's HRM system influences employee motivation levels, hence their performance. Young employees respond more readily to training programs and instructions, skills enhancement as they are quick learners and easily adapt to changes compared to their older counterparts (Graham, 2007). Younger workers also have more chances of advancing their educational levels and skills training, hence increasing their competencies and performance.

\subsection{A critique of the literature review}

From the reviewed literature, it appears that the relationship between employee age and employee performance is influenced by motivational and competency factors. Some of the studies reviewed include Grand (2005) who examined the interrelationship between cooperate age structures and employee performance. The study found that means and dispersions of age in firms were inversely U-shaped related to firm performance. Levine (2004) found a strong relationship between age race and gender on quits and dismissals. Omari (2012) found that age is not significantly related to employee outcomes. However, Karpinen (2012) found a positive relationship between employee age and employee performance.

These relationships eventually impact on the way employees perform their work and their productivity within their organizations. These mixed findings formed the basis of gaps to be addressed by this study. Both empirical and theoretical literature above elicited inadequacies and short comings highlighting gaps relating to conceptual, contextual and methodology, which this study focused on.

\section{O RESEARCH METHODOLOGY}

\subsection{Research Philosophy}

The philosophical foundation of this research is logical positivism which is a strong form of empiricism and seeks facts or causes of social phenomenon with little regard for the subjective status of individuals. This Philosophical paradigm is appropriate for a study which is anchored on theory and which seeks to test hypothesis. In positivist paradigm, the scientific process is followed in hypothesizing fundamental laws then deducing the observations so as to prove the said hypothesis. 
The approach is methodologically quantitative and value free. It is based on objectivity, neutrality, measurement and validity of results (Ananda, 2008), hence suitable for this study. The objective guided formulation of hypothesis. Research questions were based on specific objectives. To test the hypotheses, it was necessary to use quantitative data. The paradigm consistent with this method was positive paradigm.

\subsection{Research Design}

A descriptive research design was used as data was collected from a cross section of response units at one point in time. The design guides the selection of sources and types of information. It is a framework for specifying the study variables (Ntale, 2010). The choice for descriptive research design was guided by; first, it is the most efficient design for collecting data from a large number of respondents at one point in time. Secondly it allows for comparative analysis between or among organizations or a group of organizations. Thirdly, the approach enhances the credence of results by providing conclusions on data as at a given point in time (Baron, 2000).

\subsection{Population of the Study}

The target population consisted of over 100,000 employees of 187 State Corporations in Kenya, which forms the sampling frame. This population is categorized by function under five sectors (Appendix VIII) namely commercial state corporations - 34, state corporations with strategic functions - 21, executive agencies - 62, independent regulatory-25, and research, public universities and training institutions - 45, (TPRR,2014).The number of employees differ from one corporation to another depending on the nature of the core business activities

\subsection{Sample Design}

To make the study representative, the sample was drawn from the headquarters and regional offices throughout the country. The employees form the sampling frame, since employee is the unit of analysis. The sample design used was proportionate stratified sampling technique. The sample size was 384 determined using the Webster formulae described below Webster (1995) suggests the following formulae to be used to estimate the sample size.

$$
\mathbf{n}=\underline{\mathbf{Z}^{2} \pi(1-\pi)}
$$

(Error)

Where $\boldsymbol{\pi}$ is taken to be $50 \%$ proportion of the diversified employees in the state corporations. At $95 \%$ desired Level of confidence and margin error of $5 \%$ the sample size (n) is calculated as indicated below:

$$
n=\underline{(1.96)^{2}(0.5)^{2}}=384.6 \text { employees }
$$

$(\mathbf{0 . 0 5})^{2}$

The assumption made was that the study sample 384 was about $40 \%$ of the estimated population. It was therefore an ideal representative of the study population.

\subsection{Data Collection}

The study used primary data collected by use of a questionnaire on employee age, and employee performance. The researcher used questionnaire for employees to collect primary data. The questionnaire contained both structured and unstructured statements. The HR manager assisted to distribute the questionnaires equally to departments. Departmental managers in turn distributed the same basing on the categories outlined and putting in mind the three age categories. Random distribution was done in each category.

\subsection{Operationalization of the Study Variables}

Employee age was the independent variable. Employee performance was the dependent variable. HRM Practices and employee competence were the moderating variables. 
Table 3.4 Summary of Operationalization and Measures of Variables

\begin{tabular}{|c|c|c|c|c|}
\hline Variable & $\begin{array}{l}\text { Operational } \\
\text { definition/ } \\
\text { element }\end{array}$ & $\begin{array}{l}\text { Authors who } \\
\text { used similar } \\
\text { variables }\end{array}$ & Construct/Indicators & Questionnaire item \\
\hline Employee age & $\begin{array}{l}\text { 1.Generation } \\
\text { Jones } \\
\text { 2. Generation } \mathrm{X} \\
\text { 3. Generation } \mathrm{Y}\end{array}$ & William (2004) & $\begin{array}{l}\text { Employee's year of birth and age as in } \\
2015 . \\
\begin{aligned} 1 . & 1955-1965 \text { ( } 50-60 \text { years }) \\
\text { 2. } & 1966-1976 \text { ( } 39-49 \text { years }) \\
\text { 3. } & 1977-1994(21-38 \text { years })\end{aligned}\end{array}$ & $\begin{array}{l}\text { Multiple choice, Section A } \\
\text { Number } 5 \text { (Biodata) }\end{array}$ \\
\hline \multirow[t]{5}{*}{ HRM Practices } & $\begin{array}{l}\text { Employee } \\
\text { participation and } \\
\text { empowerment }\end{array}$ & $\begin{array}{l}\text { Peters and } \\
\text { Waterman } \\
(2002)\end{array}$ & $\begin{array}{l}\text {-Extent to which employees are involved } \\
\text { in decision making. } \\
\text {-Level of communication and relationship } \\
\text { between management and employees. }\end{array}$ & $\begin{array}{l}5 \text { point likert scale Part B } \\
\text { section } 1-12\end{array}$ \\
\hline & $\begin{array}{l}\text { Compensation } \\
\text { benefits (pay) }\end{array}$ & , & $\begin{array}{l}\text { Level at which employees are satisfied } \\
\text { with the pay they are given for their work } \\
\text { in the organization }\end{array}$ & $\begin{array}{l}5 \text { point likert scale Part B } \\
\text { section } 24-30\end{array}$ \\
\hline & $\begin{array}{l}\text { Employee training } \\
\text { and development }\end{array}$ & , & $\begin{array}{l}\text { Level and types of employee training. } \\
\text { Types of training facilities and types } \\
\text { offered by the organization }\end{array}$ & $\begin{array}{l}5 \text { point likert scale Part B } \\
\text { section } 13-24\end{array}$ \\
\hline & $\begin{array}{l}\text { Employee welfare } \\
\text { benefits }\end{array}$ & , & $\begin{array}{l}\text { The nature, type and adequacy of welfare } \\
\text { benefits provided by the } \\
\text { organization }\end{array}$ & $\begin{array}{l}5 \text { point likert scale Part B } \\
\text { section } 31-35\end{array}$ \\
\hline & $\begin{array}{l}\text { Performance } \\
\text { Management }\end{array}$ & , & $\begin{array}{ccc}\text { Nature and types of performance } \\
\text { management }\end{array}$ & $\begin{array}{l}5 \text { point likert scale Part B } \\
\text { section } 36-43\end{array}$ \\
\hline \multirow[t]{3}{*}{$\begin{array}{l}\text { Employee } \\
\text { competence }\end{array}$} & Educational level & $\begin{array}{l}\text { Armstrong } \\
(2000)\end{array}$ & Employee's level of education & $\begin{array}{l}\text { Multiple choice, part C } \\
\text { section 1and } 5 \text { point likert } \\
\text { scale Part } \mathrm{C} \text { section } 2 \text { no. } 1- \\
5\end{array}$ \\
\hline & $\begin{array}{l}\text { Skills level } \\
\text { Training level }\end{array}$ & , & $\begin{array}{l}\text { Level of professional training. } \\
\text { Level of training }\end{array}$ & $\begin{array}{l}\text { Multiple choice, part } \mathrm{C} 1 \\
\text { number } 4,5 \text { and } 6 \\
5 \text { point likert scale Part C } 2 \\
\text { number } 6-18\end{array}$ \\
\hline & Experience & , & $\begin{array}{l}\text { Special knowledge, talents and skills; } \\
\text { No of years worked in the organization }\end{array}$ & $\begin{array}{l}\text { Multiple choice, part A no } 8 \& \\
\text { C } 219-23\end{array}$ \\
\hline \multirow[t]{2}{*}{$\begin{array}{l}\text { Employee } \\
\text { Performance }\end{array}$} & Task performance & Muindi (2014) & $\begin{array}{l}\text { The extent to which output has increased } \\
\text { in the last five years. }\end{array}$ & $\begin{array}{l}5 \text { point likert scale Part D No } \\
1-7\end{array}$ \\
\hline & $\begin{array}{l}\text { Contextual } \\
\text { Performance }\end{array}$ & $\begin{array}{l}\text { Borman and } \\
\text { Motowidlo } \\
\text { (1993) }\end{array}$ & $\begin{array}{l}\text { Extent to which organizational, social and } \\
\text { psychological environment determines } \\
\text { employee performance }\end{array}$ & $\begin{array}{l}5 \text { point likert scale Part D No. } \\
8-16\end{array}$ \\
\hline
\end{tabular}

\subsection{Reliability and Validity of the Research Instruments}

Reliability is the degree to which measures of a given phenomena are free from random error and hence providing consistent data over time. Test-retest reliability, equivalent form reliability and internal consistency reliability were used. Internal consistency reliability examines the ability of a given data to produce similar results when different samples are used to measure a phenomenon at the same time period (McDaniel\& Gates, 2010).

Content Validity of the research instrument was carried out through a pilot test which was done by administering the research instrument to state corporation employees, 3 from each of the 5 clusters. Such questionnaire pretesting helps to identify problems with the data collection instruments and find possible solutions. Construct validity was tested by designing a set of items that matched the theoretical lining of constructs based on modified versions of previous studies and instruments of the study variables.

\subsection{Data Analysis and Presentation}

Quantitative data was analyzed using the statistical package for social sciences (SPSS). Descriptive analyses were conducted to present the main characteristics of the sample. Measures of central tendencies, mean, frequency, mode, median, index, cross tabulation and standard deviation were used in analyzing the quantitative data which was based on information from questionnaires focusing on demographic characteristics and organization characteristics. 
Inferential statistics were used to establish the magnitude and nature of the relationships between variables and to test hypothesis relationship. The parametric tests of correlation analysis and regression analysis were used. Pearson Product Moment Correlation (r) assessed relationships between the variables, specifically to determine both the direction (positive or negative) and how strong the relationship between the study variables was. This was followed by carrying out further analysis using regression. Simple linear regression, was conducted to establish the expected relationship among the variables, measure the amount of variation and determine the effect of the variation. For the hypothesis, $\left(\mathrm{R}^{2}\right)$ coefficient of determination was used to measure the amount of variation between the study variables. It also provided measure for the magnitude of dependent variable and values for predictor variables by providing estimate equations. The regression analysis was conducted at $95 \%$ level of confidence to test the hypothesis. The amount of variation between the study variables for each hypothesis was determined by the coefficient $\left(\mathrm{R}^{2}\right)$.

Simple linear regression was used to assess the relationship and the magnitude of a single independent variable (employee age) on one dependent variable (employee performance). The regression model for predicting employee performance in this analysis was as follows;

Employee performance $[E P]=f($ Employee age $[E A]) . \quad$ Where $\quad E P=\beta_{0}+\beta_{1} E A+\varepsilon$

$\mathrm{EP}=$ Employee Performance, $\beta_{0}=$ Constant, $\beta_{1}=$ Regression coefficient for employee age, $\mathrm{EA}=$ Composite index

of Employee Age and $\varepsilon=$ Error term.

\subsection{DATA ANALYSIS, FINDINGS AND DISCUSSION \\ 4.1 Relationship among the Study Variables \\ 4.1.1 Correlation among Variables}

Table 4.1 presents the results of the correlation analysis between employee performance and employee age, HRM practices and employee competence. The purpose of this correlation was to test for the magnitude, strength and direction of the relationship among the dependent, independent, and moderating variables of the study to compare the contribution of each variable in this relationship.

Table 4.1 Results of the test for the relationship between employee age, HRM practices, employee competence and employee performance.

\begin{tabular}{|l|l|l|l|l|}
\hline & $\begin{array}{l}\text { EMPLOYEE } \\
\text { PERFORMANCE }\end{array}$ & $\begin{array}{l}\text { EMPLOYEE } \\
\text { AGE }\end{array}$ & $\begin{array}{l}\text { HRM } \\
\text { PRACTICES }\end{array}$ & $\begin{array}{l}\text { EMPLOYEE } \\
\text { COMPETENCE }\end{array}$ \\
\hline EMPLOYEE PERFORMANCEE & 1 & $-.002 * *$ & $.105 * *$ & $.211 * *$ \\
\hline EMPLOYEE AGE & & 1 & $-.052 *$ & $-.001 * *$ \\
\hline HRM PRACTICES & & & 1 & $.302 * *$ \\
\hline EMPLOYEE COMPETENCE & & & & 1 \\
\hline
\end{tabular}

,** Correlation is significant at the 0.01 level (2-tailed). $p=<0.01$ (2-tailed)

* Correlation is significant at the 0.05 level (1-tailed). $p=<0.05$ (2-tailed)

Pearson product moment correlation was used to test the relationships among the study variables. The correlation results shown in Table 4.1 indicate the relationship between the dependent variable, employee performance and predictor variables namely employee age, human resource management practices and employee competence in Kenyan State Corporations and among predictor variables themselves. Results of this analysis indicate that relationship between employee performance and employee age was negative and not statistically significant $(\mathrm{r}=$ $\mathbf{0 0 2}, \mathrm{p}>0.01)$. The relationship between employee performance and human resource management practices was weak but positive $(\mathrm{r}=.105, \mathrm{p}<0.01)$ and statistically significant. There was a positive weak relationship between employee performance and employee competence which was statistically significant $(r=0.211, p<0.05)$. There 
was a negative relationship that was statistically significant between employee age and human resource management practices $(r=-.052, \mathrm{p}<0.05)$ and a negative relationship that was not statistically significant between employee age and employee competence $(\mathrm{r}=-.001, \mathrm{p}>0.01)$. Finally, relationship between HRM practices and employee competence was moderate and statistically significant $(r=0.302, p<0.01)$.

\subsubsection{Relationship between Employee Age and Employee Performance}

Assumption 1: There is a relationship between employee age and employee performance in Kenyan State Corporations

Simple linear regression analysis was conducted to test the effect of employee age on employee performance in Kenyan State Corporations. The findings are stated below.

The first stage, Model 1 tests the single relationship between employee age and employee performance. This model produced $\mathrm{R}^{2}=.001, \mathrm{~F}(1,286)=0.345, \mathrm{p}>.05$. The model reveals a statistically non significant relationship between employee age (independent variable) and employee performance (dependent variable) as the p-value $(0.557)>0.05$. The findings show $0.1 \%$ of the variation in employee performance is due to employee age. The influence of employee age on employee performance was also non significant $(\beta=0.026, t=0.587, p>0.05)$. The findings confirmed the first step in testing for variance.

\subsubsection{The effect of HRM Practices on the Relationship between Employee Age and Employee Performance} Assumption II: The effect of Employee Age on Employee Performance is moderated by Human Resource Management Practices in Kenyan State Corporations

This relationship was tested using stepwise linear regression, a method advanced by Baron and Kenny (1986). This is a regression technique in which the choice of predictive variables takes the form of sequence of F-tests or Ttests.

In stage 2 both Model 2, employee age and HRM Practices were entered into the regression equation simultaneously as presented in the Model 2, Table 4.2. This model produced $\mathrm{R}^{2}=0.069, \mathrm{~F}(2,285)=10.535, \mathrm{p}<$ .05 . As shown in the table, $6.9 \%$ of the variation in employee performance is explained by $\left(\mathrm{R}^{2}=0.069, \mathrm{~F}(2,285)\right.$ $=10.535, \mathrm{p}<0.05)$. The value of $\mathrm{R}^{2}(6.9 \%)$ implies that $93.1 \%$ in employee performance is due to other factors not included in the study. The influence of HRMP on employee performance was weak but significant $(\beta=0.181$, $\mathrm{t}=4.550, \mathrm{p}<0.05)$. For every unit change in HRMP, there is a corresponding $18.1 \%$ of change in employee performance $(\beta=0.181, \mathrm{t}=4.550, \mathrm{p}<0.05)$.

In stage three Mode 3, the interaction between employee age (independent variable) and human resource management practices (HRMP) was created. To create the interaction term, employee age (EA) and Human Resources Management Practices (HRMP) were multiplied and entered in the regression model to get a single indicator representing the product of the two variables. This model produced $\mathrm{R}^{2}=0.073, \mathrm{~F}(3,284)=20.972, \mathrm{p}<$ $0.05)$ which is statistically significant. The change of variance in age is explained by $\mathrm{R}^{2}=7.3 \%$ and a beta coefficient of $\beta=0.172(17.2 \%)$ and $t=6.248$. The findings from Table 4.3 indicate that the overall model was significant $\left(\mathrm{R}^{2}=0.073(7.3 \%), \mathrm{F}(3,284)=20.972, \mathrm{p}<.05\right.$. This confirmed assumption that HRM practices moderated the relationship between employee age and employee performance.

Table 4.2 Regression results for the moderation effect of HRM Practices on the relationship between Employee Age and Employee Performance.

a. MODEL SUMMARY

\begin{tabular}{|c|c|c|c|c|c|c|c|c|c|}
\hline \multirow[t]{2}{*}{ Model } & \multirow[t]{2}{*}{$\mathrm{R}$} & \multirow[t]{2}{*}{ R Square } & \multirow{2}{*}{$\begin{array}{l}\text { Adjusted R } \\
\text { Square }\end{array}$} & \multirow{2}{*}{$\begin{array}{l}\text { Std. Error of } \\
\text { the Estimate }\end{array}$} & \multicolumn{5}{|c|}{ Change Statistics } \\
\hline & & & & & $\begin{array}{l}\text { R Square } \\
\text { Change }\end{array}$ & F Change & df1 & $\mathrm{df} 2$ & $\begin{array}{l}\text { Sig F } \\
\text { Change }\end{array}$ \\
\hline 1 & $.035^{\mathrm{a}}$ & 0.001 & -.002 & 0.58557 & 0.001 & .345 & 1 & 286 & 0.557 \\
\hline 2 & $.262^{\mathrm{b}}$ & 0.069 & 0.062 & 0.56639 & 0.068 & 20.701 & 2 & 285 & 0.000 \\
\hline 3 & $.270^{\mathrm{c}}$ & 0.073 & 0.063 & 0.56621 & 0.004 & 1.186 & 3 & 284 & 0.277 \\
\hline
\end{tabular}


b. NNOVA $^{\mathrm{a}}$

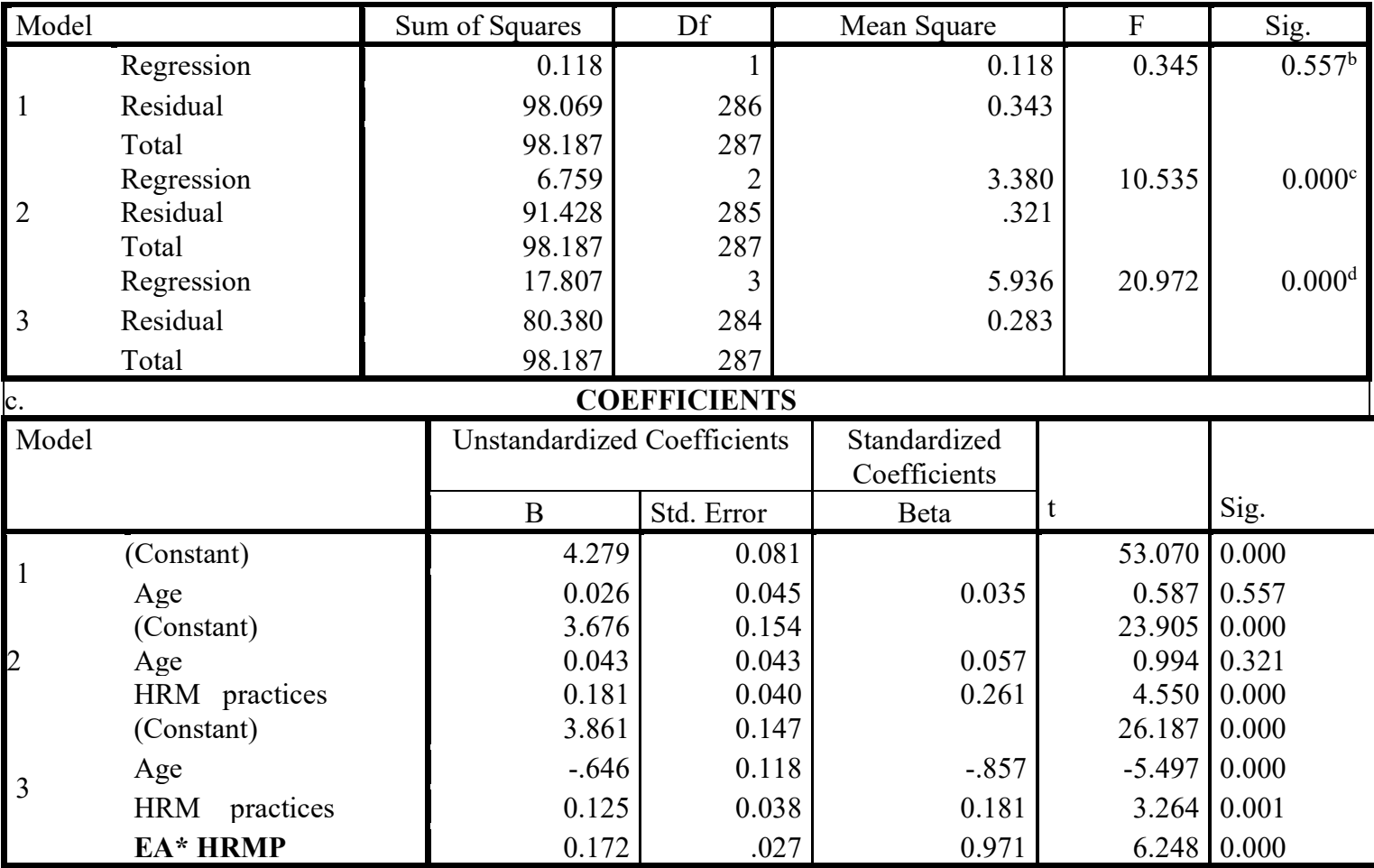

a. Dependent Variable: Employee Performance

b. Predictors: (Constant), Employee Age

c. Predictors: (Constant), Employee Age, HRM management practices d, Predictors (Constant), EA, HRMP, EA*HRP

4.1.4 The Effect of Employee Competence on the Relationship between Employee Age and Employee Performance Assumption III: The effect of employee age on employee performance is moderated by employee competence in Kenyan state corporations

The results are presented in the Table 4.3. As shown in the table, the overall regression model was significant $\mathrm{R}^{2}=$ 0.242 , (F 3,284) $=30.269, \mathrm{p}<0.05)$ implying goodness of fit. Thus, the use of the regression model for the test of assumption three was appropriate. This analysis procedure of employee competence is similar to that of HRMP stated above.

In step one Model 1, the single relationship between employee age and employee competence produced the result $\mathrm{R}^{2}=.001,(1,286)=0.345,(\mathrm{p}>.05)$. The relationship was not statistically significant.

In step two Model 2, both employee age and employee competence were entered into the regression equation simultaneously as presented in model 2 . This model produced $\mathrm{R}^{2}=0.230, \mathrm{~F}(2,285)=42.584, \mathrm{p}<.05$. At $23 \%$, the model reveals a statistically significant relationship between employee age (independent variable) and employee performance (depended variable). This implies that, a unit change of employee competence is associated with $23 \%$ variation in employee performance. Beta coefficient was $\beta=0.441,(\mathrm{t}=9.205, \mathrm{p}<.05)$ which was statistically significant. The results confirmed the second step in testing for moderation.

In step three Model 3, employee age (independent variable) is multiplied with employee competence (moderating variable) to create an interaction term, $\mathrm{EA}^{*} \mathrm{EC}$ which when entered in the regression model, brings about a change in employee performance $\left(\Delta \mathrm{R}^{2}\right)$ accounting for $\mathrm{R}^{2}=0.242, \mathrm{~F}(3,284)=30.269, \mathrm{p}<0.05$.). This is statistically significant. A unit change in employee competence explains 0.659 variation in employee performance $(\beta=0.659, \mathrm{t}$ $=5.860, \mathrm{p}<0.05)$ which is statistically significant. This confirms assumption three that employee competence moderates the relationship between employee age and employee 
Table 4.3 Regression Results for the effect of employee competence on the Relationship between Employee Age and Employee Performance

MODEL SUMMARY

\begin{tabular}{|c|c|c|c|c|c|c|c|c|c|}
\hline \multirow[t]{2}{*}{ Model } & \multirow[t]{2}{*}{$\mathrm{R}$} & \multirow[t]{2}{*}{ R Square } & \multirow{2}{*}{$\begin{array}{l}\text { Adjusted R } \\
\text { Square }\end{array}$} & \multirow{2}{*}{$\begin{array}{l}\text { Std. Error of } \\
\text { the Estimate }\end{array}$} & \multicolumn{4}{|c|}{ Change Statistics } & \multirow[b]{2}{*}{$\begin{array}{l}\text { Sig F F } \\
\text { Change }\end{array}$} \\
\hline & & & & & $\begin{array}{l}\text { R Square } \\
\text { Change }\end{array}$ & F Change & df1 & $d f$ & \\
\hline 1 & $0.035^{\mathrm{a}}$ & 0.001 & -0.002 & 0.58557 & 0.001 & 0.345 & 1 & 286 & 0.557 \\
\hline 2 & $0.480^{\mathrm{b}}$ & 0.230 & 0.225 & 0.51502 & 0.229 & 84.723 & 2 & 285 & 0.000 \\
\hline 3 & $0.492^{\mathrm{c}}$ & 0.242 & 0.234 & 0.51183 & 0.012 & 4.571 & 3 & 284 & 0.033 \\
\hline
\end{tabular}

ANOVA $^{\mathrm{a}}$

\begin{tabular}{|ll|r|r|r|r|r|}
\hline Model & & Sum of Squares & df & Mean Square & F & \multicolumn{1}{c|}{ Sig. } \\
\hline \multirow{3}{*}{1} & Regression & 0.118 & 1 & 0.118 & 0.345 & $0.557^{\mathrm{b}}$ \\
& Residual & 98.069 & 286 & 0.343 & & \\
& Total & 98.187 & 287 & & & \\
& Regression & 22.591 & 2 & 11.295 & 42.584 & $0.000^{\mathrm{c}}$ \\
& Residual & 75.596 & 285 & .265 & & \\
& Total & 98.187 & 287 & & \\
& Regression & 23.788 & 3 & 7.929 & 30.269 & $0.000^{\mathrm{d}}$ \\
& Residual & 74.399 & 284 & .262 & & \\
\hline
\end{tabular}

COEFFICIENTS

\begin{tabular}{|c|c|c|c|c|c|c|}
\hline \multirow[t]{2}{*}{ Mod } & & \multicolumn{2}{|c|}{ Unstandardized Coefficients } & \multirow{2}{*}{$\begin{array}{c}\text { Standardized } \\
\text { Coefficients }\end{array}$} & \multirow[t]{2}{*}{$\mathrm{t}$} & \multirow[t]{2}{*}{ Sig. } \\
\hline & & $\mathrm{B}$ & Std. Error & & & \\
\hline \multirow{3}{*}{1} & (Constant) & 4.279 & 0.081 & \multirow{3}{*}{0.035} & 53.070 & 0.000 \\
\hline & Age & 0.026 & 0.045 & & 0.587 & 0.557 \\
\hline & (Constant) & 2.529 & 0.203 & & 12.463 & 0.000 \\
\hline \multirow[t]{3}{*}{2} & Age & 0.022 & 0.039 & \multirow{3}{*}{$\begin{array}{l}0.029 \\
0.478\end{array}$} & 0.552 & 0.582 \\
\hline & Employee Competence & 0.441 & 0.048 & & 9.205 & 0.000 \\
\hline & (Constant) & 1.665 & 0.452 & & 3.686 & 0.000 \\
\hline \multirow{3}{*}{3} & Age & 0.537 & 0.244 & 0.712 & 2.199 & 0.029 \\
\hline & Employee Competence & 0.659 & 0.113 & 0.715 & 5.860 & 0.000 \\
\hline & $\mathbf{E A} * \mathbf{E C}$ & 0.172 & 0.061 & -.734 & -2.138 & 0.033 \\
\hline
\end{tabular}

a. Dependent Variable: Employee Performance b. Predictors: (Constant), Employee Age

c. Predictors: (Constant), Employee Age, Employee competence

d. Predictors: (Constant), Employee Age, Employee competence, Employee Age * Employee competence.

4.2 Joint Effect of Employee Age, HRM Practices and Employee Competence on Employee Performance. The main objective of the study sought to establish whether the joint effect of employee age, human resource management practices and employee competence on employee performance was greater than the effect of the individual predictor variables on employee performance in Kenyan state corporations. The joint effect of the study variables is compared with the effect of the mean/average aggregate individual predictor variables on employee performance. To test this effect the following hypothesis was formulated.

Hypothesis of the study: The joint effect of employee age, human resource management practices and employee competence is greater than the effect of individual predictor variables on employee performance

The Hypothesis was tested using multiple linear regression model. Table $4.5 \mathrm{a} \mathrm{b}$ and $\mathrm{c}$ shows the results of the regression. The following results were obtained. The overall model shown in Table 4.5 a, generated $R^{2}=0.438, F$ 
$(4,283)=1.935,(p<0.05)$. Employee age, HRM Practices and Employee competence explained $43.8 \%$ of the variance in employee performance $\left(\mathrm{R}^{2}=0.438\right)$, which was statistically significant at $(\mathrm{p}<0.05)$. Table $4.5 \mathrm{~b}$ presents Regression outcomes (ANOVA results) of the Joint effect of employee age, HRM Practices and employee competence on employee performance. The $\mathrm{F}$ values were $\mathrm{F}(4,283)=31.025$. $\mathrm{P}<0.05$. which was statistically significant.

Table $4.5 \mathrm{c}$ shows the Regression coefficients for the joint effect of Employee Age, HRM Practices and Employee Competence on Employee Performance. The regression coefficient B for Employee age in the presence of HRMP and EC is 0.290 , with a $\mathbf{t}$ value of 3.567 and a significance level ( $\mathrm{p}$ value $<0.05$ ). The regression coefficient $\mathrm{B}$ value for the moderating variable HRM Practices in the presence of EA and EC was 0.120, with a $\mathbf{t}$ value of -2.194 and a significance level ( $\mathrm{p}$ value $<0.05$ ). This implies that employee competence had a significant impact on employee performance in the presence of human resource practices and employee age.

The above results can be compared with results of individual predictor variables shown in Table 4.2 and 4.3 as follows; The regression coefficient for employee age alone indicated $\mathrm{B}=0.060, \mathbf{t}=0.787$ and a significance level of $(p-$ value $>0.05)$. Human resource management practices alone indicated a regression coefficient of $B=0.120$, $\mathbf{t}=2.194,(\mathrm{p}<0.05)$ and Employee competence alone indicated a regression coefficient of $\mathrm{B}=0.441, \mathbf{t}=0.205,($ $\mathrm{p}<0.05)$. The joint effect of EA, HRM $\mathrm{P}$, and EC on employee performance indicated $\mathrm{B}=0.290, \mathbf{t}=3.567(\mathrm{p}<$ 0.05), Employee Competence explained $29.0 \%$ of the variance in employee performance.

For individual predictor variables, the research findings indicated that the mean Employee Age, Human Resource Management Practices and Employee Competence explained 20.7\% of the variance in employee performance $(B=0.207)$. The overall model reveals a statistically significant relationship between employee performance and the mean of Employee Age, HRM P, and E $(p<.05)$

The results confirm the study hypothesis, that the joint effect of employee age, human resource management practices and employee competence on employee performance $\mathrm{R}^{2}=0.4389(43.9 \%), \mathrm{B}=0.290, \mathrm{t}=3.567(\mathrm{p}<$ $.05)$ is greater than the effect of the mean individual predictor variables $R^{2}=0.273, B=0.207, t=(p<.05)$ as shown above. This comparison indicates that the effect of individual predictor variables was less than the joint effect of the predictor variables.

Table 4.4 Results of Regression of the joint effect of employee age, HRMP and employee competence on employee performance

\section{a) MODEL SUMMARY}

\begin{tabular}{|c|c|c|c|c|c|c|c|c|c|}
\hline \multirow[t]{2}{*}{ Model } & \multirow[t]{2}{*}{$\mathrm{R}$} & \multirow[t]{2}{*}{ R Square } & \multirow{2}{*}{$\begin{array}{l}\text { Adjusted R } \\
\text { Square }\end{array}$} & \multirow{2}{*}{$\begin{array}{l}\text { Std. Error of } \\
\text { the Estimate }\end{array}$} & \multicolumn{5}{|c|}{ Change Statistics } \\
\hline & & & & & $\begin{array}{c}\text { R Square } \\
\text { Change }\end{array}$ & F Change & df1 & $\mathrm{df} 2$ & $\begin{array}{l}\text { Sig F } \\
\text { Change }\end{array}$ \\
\hline 1 & $0.665^{\mathrm{a}}$ & 0.438 & 0.227 & 0.4489 & 0.438 & 1.935 & 4 & 283 & 0.000 \\
\hline
\end{tabular}

b) ANOVA ${ }^{\mathrm{a}}$

\begin{tabular}{|rl|r|r|r|r|c|}
\hline Model & Sum of Squares & Df & Mean Square & F & Sig. \\
\hline \multirow{3}{*}{1} & Regression & 24.236 & 3 & 8.079 & 31.025 & $.000^{\mathrm{b}}$ \\
& Residual & 73.951 & 284 & .260 & & \\
& Total & 98.187 & 287 & & & \\
\hline
\end{tabular}




\begin{tabular}{|c|c|c|c|c|c|}
\hline REG & ION C & FICIENTS & & & \\
\hline \multirow[t]{2}{*}{ Model } & \multicolumn{2}{|c|}{$\begin{array}{c}\text { Unstandardized } \\
\text { Coefficients }\end{array}$} & $\begin{array}{l}\text { Standardized } \\
\text { Coefficients }\end{array}$ & \multirow[t]{2}{*}{$\mathrm{t}$} & \multirow[t]{2}{*}{ Sig. } \\
\hline & B & Std. Error & Beta & & \\
\hline \multirow[t]{2}{*}{ (Constant) } & 2.356 & 0.212 & & 3481 & 0.000 \\
\hline & 0.060 & 0.070 & 0.041 & 0.787 & 0.432 \\
\hline \multirow{4}{*}{$\begin{array}{ll}\text { 2. } & \text { HRM management } \\
\text { practices } \\
\text { 3. } \\
\\
\text { 4. } \\
\text { Employee Competence } \\
\end{array}$} & 0.120 & 0.050 & -0.192 & -2.194 & 0.030 \\
\hline & 0.441 & 0.048 & 0.478 & 9.205 & 0.000 \\
\hline & & & & & \\
\hline & 0.290 & 0.081 & 0.263 & 3.567 & 0.000 \\
\hline
\end{tabular}

a. Dependent Variable: Employee Performance

b. Predictors: (Constant), Employee Age, Employee Competence, HRM management practices

The overall model indicated that there was a significant influence of the joint effect of employee age, human resource management practices and employee competence on employee performance. $\mathrm{R}^{2}=0.438, \mathrm{~F}(4,283)=$ $31.025,(\mathrm{p}<.05)$. Meaning that employee age, HRM Practices and employee competence explained $43.8 \%$ of the variance in employee performance $\left(\mathrm{R}^{2}=0.438\right)$, which was statistically significant at $(\mathrm{p}<.05)$. The multiple regression model with the mean of all the three predictors (Employee Age, Human Resource Management Practices, Employee competence) produced $\mathrm{R}^{2}=0.207, \mathrm{~F}(3,285)=42.5, \mathrm{p}<.05$.

The research findings indicated that the mean Employee Age, Human Resource Management Practices and Employee Competence explained $20.7 \%$ of the variance in employee performance $\left(\mathrm{R}^{2}=0.207\right)$. The overall model reveals a statistically significant relationship between employee performance and the mean of EA, HRM P, and E $(\mathrm{p}<.05)$ The results confirm the study hypothesis, that the joint effect of employee age, human resource management practices and employee competence on employee performance $\left(R^{2}=0.438\right), B=0.290, t=3.567(p$ $<.05)$ is greater than the effect of mean individual predictor variables $\mathrm{R}^{2}=0.273, \mathrm{~B}=0.207, \mathrm{t}=(\mathrm{p}<.05)$ as shown above.

\section{Discussion}

The objective of the study sought to determine the difference between the joint effect of Employee Age, HRM Practices and Employee Competence on Employee Performance and the effect of individual predictor variables on performance. The study predicted that jointly Employee Age, HRM Practices and Employee Competence had a stronger effect on employee performance than the mean effect of the three individual predictor variables.

The research findings indicated that overall, the joint effect of Employee Age, HRM Practices and Employee Competence on employee performance was significant. The joint effect recording $43.8 \%$ score $\left(\mathrm{R}^{2}=0.438\right), \mathrm{F}(4$, $283)=31.025,(\mathrm{p}<.05)$. The contribution of individual predictor variables is shown in the table 4.4. This follows that the joint effect of the predictor variables was greater than the average aggregate effect and hence the hypothesis was accepted. These findings support a related study carried out by Muindi (2014) in the Kenyan public universities which also found that the joint effect of the study variables was stronger than the effect of the individual predictor variables. The final objective of the Muindi's study aimed at determining difference between the joint effect of Quality work Life, personality, job satisfaction and competence on employee performance and the average aggregate of the effect of all predictor variables on performance.

The joint effect of the predictor variables was greater than the individual effect and hence the hypothesis was accepted. Despite the fact that public universities are State Corporations, their management, facilities and core functions could differ with other State Corporations and hence comparing the regression results without putting other factors into consideration may not help much. In addition the current study focused on employee age and employee performance as Muindi (2014) focused on Quality Work life (QWL) and performance. 
The results of Omari (2012) study indicated that the joint effect of the cognitive and contextual factors on the relationship between employee characteristics and employee outcomes was greater than of the effects of the individual predictor variables. Findings indicated that the effect of the individual independent and moderating variables is not greater than their joint effect. Thus, the hypothesis which stated that the joint effect of the independent and moderating variables on employee outcomes (trust, job satisfaction, organization commitment and citizenship behaviors) is greater than the individual effect of the independent and moderating factors on employee outcomes was supported. Luthan (2000) indicated that employee behavior is influenced by such factors as job satisfaction, group dynamics, motivation, attitudes, stress, personality and leadership among others. The results of the model revealed that competence significantly predicted employee performance. From the results of the test of hypothesis, it is evident that age, in spite of what other studies such as (Hickson and Oshagbemi (1991) found, does not have any significant role in the determination of employee performance as shown in Table 4.2 and 4.3. Looking at the $\mathrm{R}^{2}$ and Beta values in respect of this study, one notes that the contribution of age was not significant for all the relationships. These results were unexpected and they contradict those of other previous studies. The findings can be partly attributed to the fact that age in the questionnaire was asked in form of class intervals while previous studies used actual individual ages. These results raise a lot of questions on whether the methodology used to collect the information on employee age was faulty or whether the Kenyan State Corporations environment have a different business context to the extent that age does not affect any of the employee behaviors. However age was moderated significantly by HRM Practices and employee competence. The joint effect of the predictor variables is stronger than the aggregate individual predictor variables.

\subsection{SUMMARY, CONCLUSIONS AND RECOMMENDATIONS}

\subsection{Summary.}

The study hypothesis: The joint effect of employee age, human resource management practices and employee competence is greater than the effect of individual predictor variables on employee performance. To establish the joint effect of Employee Age, HRM Practices and Employee Competence on Employee Performance, all the three predictor variables were regressed using multiple regression technique. The predictors generated a regression model. The model generated was $\mathrm{R}^{2}=0.438, \mathrm{~F}(4,283)=1.995,(\mathrm{p}<.05)$. The study established that employee age, HRM Practices and Employee competence recorded $43.8 \%$ of the variance on employee performance $\left(\mathrm{R}^{2}=\right.$ 0.438), which was statistically significant. This implied that the joint effect of employee age, HRM Practices and employee competence is greater than the effect of individual predictor variables on employee performance as shown on table 4.5 which confirms the study hypothesis.

\subsection{Concusion .}

The study sought to establish whether the joint effect of Employee Age, HRM Practices and Employee Competence on Employee Performance is greater than the effect of individual predictor variables on employee performance in state corporations. Multiple regression was used. All the three predictor variables were regressed using multiple regression technique. The study established that employee age, HRM Practices and Employee competence recorded $43.8 \%$ of the variance on employee performance $\left(R^{2}=0.438\right)$, which was statistically significant. This implied that the joint effect of employee age, HRM Practices and employee competence is greater than the effect of individual predictor variables on employee performance which was statistically significant, confirming the study hypothesis. Employee age, HRM Practices and employee competence $(\mathrm{p}<.05)$ Some sub variables of HRM Practices including employee participation and empowerment, fair and adequate compensation and performance management had recorded a statistically non significant relationship with employee performance. For compensation they included, assisting and cooperating with other workers and endorsing and following organization rules and policies. The joint effect contributed more to employee performance than the individual predictor variables.

\subsection{Reccommenations}

The implication is that the influence of age on employee performance is weak and therefore age should not be given the much weight it has been awarded in major employment decisions.

There was a statistically joint significant relationship between employee age, HRM Practices and employee competence on employee performance $(\mathrm{p}<.05)$. Hypothesis for the study was accepted. The findings have practical implications for organization decision making by management. State corporations should apply these variables jointly to maximize their employee performance. Individual predictor variables have a lesser effect. 


\section{REFERECES}

Achoti, N, G. (2011). Factors influencing employee performance appraisal. Interntional Journal of Business and Social sciences. Vol. 3, No 20. Pp $54-73$.

Ackerman, P. (2014). Employee age. London: Prentice hill.

Adams, T. (2013). Human Resource Management.Journal of Management. Vol.13(1), pp1- 24.

Ananda, J. and McCann, J. (2008).Human Resource Planning. The Changing definition of Organisation Effectiveness. Nairobi:Penguin.

Barbara, R. (2026). Age and Employment. New York: Free Press

Baron, E. (2000). Human Resource Management.Models of Entrepreneurship.Vol.31(4), Pp36-59.

Bonsdorff, M. (2016). An intergrated model of aging and HRM Practices. Jom editorial board

Borman, W. C., White, L. A., Pulakos, E. D. and Oppler, S. H. (1991).Models of supervisory job performance ratings Journal of Applied Psychology, 76, 863-872.

Boulander, G. (2007). Human Resource Management. London: NartopBoulevard Mason.

Casey, M. and Dave, L, L.(2007). Human Resource Strategies and the Third Age:Policies and Practices in the UK London: Mercury books.

Campbel, J. P. (2013). Moderating Performance Production in Institutional and Organizational Psychology. San Fransico: Sage Press.

Cole, G, Armstrong. (2008). Personnel and Human Resource Management. $5^{\text {th }}$ Edition; London:Prentice hill.

Dalton, B. and Thomas S. (2008). Human Resource Management. London: Prentice hill..

David, M. and Stephen, D. (2010) Human Resource Management. London. Prentice Hill.

Delsen, L. and Reday, G. (2009). Gradual retirement in the developed countries. Dictionary for business. Macmilan publishers, Nairobi.

Eiker, S. (2009).European Economic Bulletin. Social Network Interaction.Dublin. London.

Feldman, S and Stamin,P.(1989). Human Resource Management. $2^{\text {rd }}$ Edition; London.

GOK (2015). State Corporations Act (Cap 446) of the laws of Kenya. Nairobi: Governme Printers.

Graham, H. and Bernnet R. (2007). Human Resource Management. $9^{\text {th }}$ Edition. London. Norton.

Grand,T. (2005) .Organisational commitment. London: Prentice hill.

Green, Jand Guillemard,J.(2005). Older people in Europe. Social and Economic Policies; Brussels, E.C Commission.

Hickson, C and Oshagbemi, T. (1999) "The effect of age on the satisfaction of academics with teaching and research" International Journal of Social Economics Vol.26 No.4 pp 537-544

James, J. B., Mckechnie, S., and Swanberg, J. (2011). Predicting employee engagement in an age-diverse retail workforce. Journal of Organizational Behavior, Vol.3 pp.173-196

Kafner M., Kangas, M., Lamsa, A. M.andFeldt, T. (2014).The leadership-culture connection among Finnish managers. Leadership \& Organization Development Journal,vol. 34: pp 250-270.

Kanagaraj, F. (2017) Human Resource Management. A diagnostic Approach, New York: Gilmore.

Karpinnen, J. (2011). Combating age barriers in employment. Dublin, Harries

Karrugah, R. (2004). Population and employment in developing world. Nairobi. Macmillan publishers

Leman, W.H., Bolino M.C., Lester S.W and Bloodgood J M. (2003) "The impact of psychological contract fulfillment on the performance of in-role and organizational citizenship behaviours" Journal of Management Vol. 29 No.2 pp. 187-206.

Levine, D. (2004). Employee outcomes. European research report, Dublin: Haries publishers.

Lidden, F. (2007). Human Resource Management. Edinburg: Gate.

Maddox, M. and Robert, I. (2017). The best page in the universe. Makest media. San Diego.

Maitland, S. B., Intriesi, R.C. and Willis, S. L. (2013). Age and performance. Journal of Management: Vol.7, No 1, pp 32-53.

Menounis, M. (2015). Labor and employment law. New York. Albrow press.

Mowday, L.(2009). Performance Career Stages. London: Thomas Learning.

Muindi, F. K. (2014). Quality of work life, personality, job satisfaction, competence and job performance of academic staff in public universities. Unpublished PhD Thesis, University of Nairobi. Kenya. 
Munjuri, G.M (2013). Human capital, social capital, employee empowerment, quality of Decisions and Performance of commercial banks and insurance companies.

Musyoka, M. (2010). Factors influencing the relationship between stress and corporate performance in publicly quoted companies at the Nairobi Stock Exchange.

Ntale,J. (2010).The Influence of Entrepreneurship on livelihood Outcomes of Small Scale Famers in Kenya. Unpublished PhD Thesis. University of Nairobi; Kenya.

Obare, T. and Norton, G. (2006). Managing for healthy profits. Nairobi: Mercury books.

Omari, S. (2012). The Influence of Contextual and Cognitive Factors on the Relationship between Employee Characteristics and Employee Outcomes in Kenyan Public .

Orneistein, C.(2011). Performance Career Stages. New York: Free Press.

Oshagbemi T. (2004) "Age influences on the leadership styles and behaviour of managers" Employee Relations Vol.26. No. 1 pp 14-29

Reday, D. M. (1998). Is length of employment related to job satisfaction? Retrieved August 30, 2005, from http://clearinghouse. missouriwestern.edu/manuscripts/98.asp

Richard, J. (2004). Human Resource Management. Edinburg: Gate.

Schuler, R. S. and Jackson, S. E., (2009). Linking competitive strategies with human resource practices. The Academy of Management Executive (1987-1989), pp 207-219.

Schular, T. (2009). Age and the workgroup. Journal of behavior. Vol,3(4), pp $56-62$.

Smith, R. (2017). Human Resource Management. Edinburgh: Gate.

Snell, S. and Bohlander, G. (2007). Human Resource Management,Boulevard:Nartop.

Staw, B. M. (2006). Corporate Psychology andPursuit of the productive worker. Carlifornia: Gate

Stephen, T. and Snape,G. (2000). "Too old or too young? The impact of perceived age discrimination, Human Resource Management journal, vol.13 (1), pg 78 - 89.

Swarthert, M. (2015).Employee age. Michigan: Instant publishers.

Taxiler, M. Donel. (2008). Age and work performance Myths and realities. London: Routlege.

Twit,H. and Feldman, D. (2008). The relationship of age to ten dimensions of job performance. Journal of applied Psychology, vol 2, pp 392 - 423. USD [United States Department Of Labour]( 2012): Cohesion policy in organization growth.New York :Nostrand;

Waang, C. Frye, G. and Peters, E. (2016). Determination of Age. Working paper 56. University of Sydney. Retrieved from http/waba/. Age,org/info.

Webster,A. L. (1995).Applied statistics for Business and Economics, $2^{\text {nd }}$ Edition, USA: Irwin. 